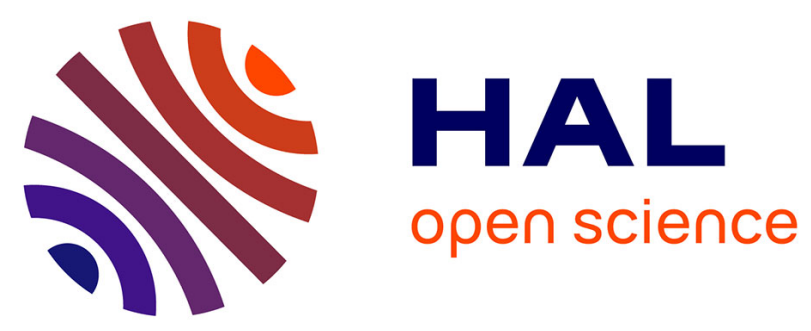

\title{
Nanometric nickel exsolution in the hexagonal perovskite Ba8Ta6NiO24: Survey of the structural, magnetic and catalytic features
}

Tanguy Pussacq, Olivier Mentre, Franck Tessier, Axel Löfberg, Marielle Huve, Jesús Guererro Caballero, Silviu Colis, Houria Kabbour

\section{To cite this version:}

Tanguy Pussacq, Olivier Mentre, Franck Tessier, Axel Löfberg, Marielle Huve, et al.. Nanometric nickel exsolution in the hexagonal perovskite Ba8Ta6NiO24: Survey of the structural, magnetic and catalytic features. Journal of Alloys and Compounds, 2018, 766, pp.987 - 993. 10.1016/j.jallcom.2018.07.016 . hal-01835091

\section{HAL Id: hal-01835091 \\ https://hal.science/hal-01835091}

Submitted on 10 Sep 2018

HAL is a multi-disciplinary open access archive for the deposit and dissemination of scientific research documents, whether they are published or not. The documents may come from teaching and research institutions in France or abroad, or from public or private research centers.
L'archive ouverte pluridisciplinaire HAL, est destinée au dépôt et à la diffusion de documents scientifiques de niveau recherche, publiés ou non, émanant des établissements d'enseignement et de recherche français ou étrangers, des laboratoires publics ou privés. 


\title{
Nanometric Nickel Exsolution in the Hexagonal Perovskite $\mathrm{Ba}_{8} \mathrm{Ta}_{6} \mathrm{NiO}_{24}$ : Survey of the Structural, Magnetic and Catalytic features
}

Tanguy Pussacq, ${ }^{a}$ Olivier Mentréa, Franck Tessier, ${ }^{b}$ Axel Löfberg, ${ }^{a}$ Marielle Huvé, ${ }^{a}$ Jesus Guererro Caballero, ${ }^{a}$ Silviu Colis, ${ }^{c}$ Houria Kabbour ${ }^{\mathrm{a}, *}$

*houria.kabbour@univ-lille1.fr

${ }^{a}$ Univ. Lille, CNRS, Centrale Lille, ENSCL, Univ. Artois, UMR 8181 - UCCS - Unité de Catalyse et Chimie du Solide, F-59000 Lille, France

b Institut des Sciences Chimiques de Rennes (UMR CNRS 6226), Verres et Céramiques, Université de Rennes 1, 263 avenue du Général Leclerc, F-35042 Rennes cedex, France

${ }^{\mathrm{c}}$ IPCMS, Strasbourg-France

KEYWORDS: Oxide $\bullet$ Hexagonal Perovskite $\bullet$ Ammonia $\bullet$ Nickel $\bullet$ Exsolution

\begin{abstract}
Nickel nanoparticles that decorate the surface of a parent oxide are well known to be developed by some cubic-type perovskites from the exsolution of their intrinsic $\mathrm{Ni}^{2+}$ species in reducing conditions with subsequent catalytic properties. In this work, we show similar phenomenon in a hexagonal-type perovskite. The reducing treatment in ammonia of $\mathrm{Ba}_{8} \mathrm{Ta}_{6} \mathrm{NiO}_{24}$, a hexagonal perovskite-type oxide, leads to the exsolution of Nickel nano-sized particles at the surface of the precursor leaving oxygen vacancies and partially depleted but rearranged $\mathrm{Ni} / \mathrm{Ta}$ sites. Spectroscopic methods, X-ray diffraction, TEM and TGA were employed to investigate the $\mathrm{Ni}$ exsolution while TGA was used to investigate the thermal behavior and its reversibility. $50 \%$ of the initial nickel content transferred into $\mathrm{Ni}^{0}$ nanoparticles as determined from $M(H)$ magnetization plots and TGA, in agreement with the concomitant creation of oxygen vacancies in the preserved $\mathrm{Ni}^{2+}$ coordination (50\%). The cationic vacancies $\left(\mathrm{V}_{c}\right)$ involve face-sharing octahedral dimers in which $\mathrm{Ni} / \mathrm{Ta} / \mathrm{V}_{\mathrm{c}}$ rearranged
\end{abstract}


through the shared face window, but preserves a non-centrosymmetric cationic partition. Ni exsoluted oxides often show a catalytic activity; we present here an original example of a hexagonal perovskite with catalytic activity toward syngas production by reforming of methane with carbon dioxide.

\section{Introduction}

In reducing conditions, a wide range of processes take advantage of metal nanoparticles exsoluted at the surface forming dual catalytic systems that find applications in various fields of the chemical and energy industries. For example, the reversible exsolution of $\mathrm{Cu}^{0}$ dendrites in copper vanadates upon Li-intercalation turned into a promising direction for the development of an alternative class of high energy density Li storage electrodes [1]. In the field of catalysis, it has been shown that exsoluted catalysts are less sensitive to coking due to the optimal metal-support interaction, in particular in Nickel based perovskites [2, 3]. In the same way, steam electrolysis is improved with Fe-exsoluted perovskite-based catalysts [4]. Upon oxidation, we have studied recently the metal exsolution of up to $1 / 3^{\text {rd }}$ metal oxides (i.e. $\alpha-\mathrm{Fe}_{2} \mathrm{O}_{3}$ ) in $\mathrm{Fe}^{2+}$ oxo-anion compounds such as $\mathrm{BaFe}_{2}\left(\mathrm{PO}_{4}\right)_{2}$ [5] leading to sizeable particles with potential photocatalytic properties [6-7] and striking topochemical structural rearrangements. Various applications might be improved by exsolution-based materials as shown for instance in the field of photocatalysis [8] and SOFC [9]. The great advantages of anchored particles for catalysis (and other functionalities), i.e. in exsolution-based systems, have been now assessed by advanced studies in the recent literature [10].

It allows overcoming limitations of the most common techniques in which the metal nanoparticles of supported catalysts are generated at the surface using deposition methods and impregnation techniques. The later provide limited control over final properties of the catalyst, like interaction with the support at short and long term [11, 12] leading to loss of catalytic efficiency from cocking or agglomeration of the nanoparticles [13, 14], including in processes like the Dry Reforming of Methane (DRM) or syngas production. 
Some recent studies specifically deal with Ni-based perovskites and their ability to exsolute $\mathrm{Ni}$ nanoparticles at their surface in reductive conditions leading for instance to potentialities as hydrogen electrode for SOFC [15], or enhancement of their catalytic properties [10]. Several reports showed that exsolved particles can make supported catalysts more resilient to agglomeration and coking, although the detailed features of this improvement are not well understood yet [16-18]. Recently, we have evidenced an original and performant catalytic system elaborated from the reductive decomposition of $\mathrm{BaNi}_{2} \mathrm{~V}_{2} \mathrm{O}_{8}$ with full nickel exsolution, which shows a remarkable stability. [19]

In this context, we have investigated the cation-deficient $\mathrm{Ba}_{8} \mathrm{Ta}_{6} \mathrm{NiO}_{24}$ hexagonal perovskite. It exists in two crystalline forms, the cubic one prepared in molten salts below $1200{ }^{\circ} \mathrm{C}$ and the hexagonal one prepared by solid state reaction at $1350{ }^{\circ} \mathrm{C}$ [20]. The hexagonal form along with the Co, $\mathrm{Cu}$ and $\mathrm{Zn}$ substituted ones have been investigated in 2006 by A. Kan et al., [21] dealing with the dependence of the dielectric properties on the covalence of the M$\mathrm{O}$ bonds. Other isostructural compounds like $\mathrm{Ba}_{8} \mathrm{Ta}_{4} \mathrm{Ru}_{8 / 3} \mathrm{CO}_{2 / 3} \mathrm{O}_{24}$ [22], $\mathrm{Ba}_{8} \mathrm{Ta}_{6} \mathrm{MgO}_{24}$ [23], and $\mathrm{Ba}_{8} \mathrm{Ta}_{4+\mathrm{x}} \mathrm{Ga}_{4-\mathrm{x}} \mathrm{O}_{24}$ [24] have also been reported to show interesting dielectric properties [2527]. Different synthesis routes were also investigated to study the impact on the microwave dielectric properties [ref 20].

We report here the topotactic exsolution of nano-sized $\mathrm{Ni}$ particles from the parent hexagonal perovskite oxide $\mathrm{Ba}_{8} \mathrm{Ta}_{6} \mathrm{NiO}_{24}$ under reductive atmosphere in $\mathrm{NH}_{3}$ gas at relatively high temperature. Besides the characterization of the exsoluted $\mathrm{Ba}_{8} \mathrm{Ta}_{6} \mathrm{NiO}_{24}$ phase, a preliminary study of its aptitudes for catalytic Dry Reforming of Methane is given. While potentialities and advantages of standard perovskites have been shed into light, to the best of our knowledge, such study on a Hexagonal Perovskite is original. Local structural rearrangements take place in the later while the surface of the solid is decorated by $\mathrm{Ni}$ nanoparticles. The aim of this work is to present remarkable and reversible topotactic phenomena in a hexagonal perovskite, and their potentialities for DRM catalysis.

\section{Experimental Methods}

Synthesis: $\mathrm{Ba}_{8} \mathrm{Ta}_{6} \mathrm{NiO}_{24}$ was prepared by solid state reaction from a mixture of $\mathrm{BaCO}_{3}(99 \%$, Sigma Aldrich) dried at $400^{\circ} \mathrm{C}, \mathrm{Ta}_{2} \mathrm{O}_{5}$ (99.99\%, Sigma Aldrich) and $\mathrm{NiO}$ (99.8\%, Sigma Aldrich) in stoichiometric amount. These precursors were ground in an agate mortar in 
acetone, pelletized and heated at high temperature in air in an alumina crucible. Following the procedure reported in the literature [28], the annealing temperatures and times were $1150{ }^{\circ} \mathrm{C}$ for $24 \mathrm{~h}$ and $1350{ }^{\circ} \mathrm{C}$ for $40 \mathrm{~h}$ with intermediate grindings and pelletizations. We note in the final product a minor amount of $\mathrm{Ba}_{5} \mathrm{Ta}_{4} \mathrm{O}_{15}$. Polycrystalline $\mathrm{Ba}_{8} \mathrm{Ta}_{6} \mathrm{NiO}_{24}$ phase was placed in an alumina boat and heated in a flow of ammonia with a flow rate of $30-401 . \mathrm{h}^{-1}$ in the temperature range of $400-1000{ }^{\circ} \mathrm{C}$, with a heating rate of $10^{\circ} \mathrm{C} / \mathrm{min}$. After a reaction time of $8 \mathrm{~h}$, the furnace was switched off and the final product was cooled down to room temperature in a pure nitrogen atmosphere.

Nitrogen and oxygen contents were determined with a LECO ${ }^{\circledR}$ TC-600 analyzer using the inert gas fusion method. Nitrogen was measured as $\mathrm{N}_{2}$ by thermal conductivity and oxygen as $\mathrm{CO}_{2}$ by infrared detection. The apparatus was calibrated using Leco $^{\circledR}$ standard samples.

The catalytic activity was measured at atmospheric pressure in a U-shaped fix-bed reactor with an inner diameter of $4 \mathrm{~mm}$, electrically heated in a furnace and connected to a flow apparatus equipped with mass flow controllers. Typically, $100 \mathrm{mg}$ of catalyst as powder was placed in the reactor between two layers of quartz wool. The reaction temperature is measured by a K-type thermocouple placed near to the catalytic bed. The standard reagent gas mixture consisting of 5 vol\% $\mathrm{CH}_{4}, 5$ vol\% $\mathrm{CO}_{2}, 10$ vol\% $\mathrm{He}$ and 80 vol\% Ar was led over the catalyst at a flow rate of $100 \mathrm{~mL}$ min-1, equivalent to a weight hourly space velocity (WHSV) of $60000 \mathrm{~mL} \mathrm{gcat}^{-1} \mathrm{~h}^{-1}$ at atmospheric pressure. The catalytic conversions were measured at $800{ }^{\circ} \mathrm{C}$ for $4 \mathrm{~h}$. The effluent gases were analyzed on line by a quadrupole mass spectrometer with a continuous secondary electron multiplier (C-SEM) as a detector.

X-ray diffraction (XRD) data was collected on a Bruker AXS D8 Advance X-ray diffractometer ( $\theta-2 \theta$ scan mode, back monochromatized $\mathrm{Cu}-\mathrm{K}_{\alpha}$ radiation) equipped with a LynxEye fast detector). The XRD-based refinements were performed using the program FULLPROF [29].

Thermogravimetric analysis (TGA) on $\mathrm{Ba}_{8} \mathrm{Ta}_{6} \mathrm{NiO}_{24}$ after $\mathrm{NH}_{3}$-treatment was carried out using a TGA 92-1600 SETARAM analyzer, under recomposed air (20\% $\mathrm{O}_{2}$ and $80 \% \mathrm{~N}_{2}$ ) flow, from room temperature to $1300^{\circ} \mathrm{C}$ and back to ambient temperature. 
Transmission electron Microscopy (TEM) experiments were carried out on a FEI Technai G220 twin TEM microscope. The powder was crushed and dropped in the form of alcohol suspension on carbon supported copper grids followed by evaporation under ambient condition.

TGA under $\mathrm{H}_{2}$ : The reducibility of $\mathrm{Ba}_{8} \mathrm{Ta}_{6} \mathrm{NiO}_{24}$ was studied by thermogravimetric analysis (TGA) on a Hiden Isochema (IGA 003) instrument in $10 \% \mathrm{H}_{2} / \mathrm{N}_{2}$. A preliminary degassing under secondary vacuum at ambient temperature was applied, then atmospheric pressure was reinstalled by incorporating $\mathrm{N}_{2}(50 \mathrm{~mL} / \mathrm{min})$ during 6 hours. The gas was then switched to $10 \% \mathrm{H}_{2} / \mathrm{N}_{2}(50 \mathrm{~mL} / \mathrm{min})$. The temperature was increased at a rate of $5^{\circ} \mathrm{C} / \mathrm{min}$ up to $1000^{\circ} \mathrm{C}$ and kept at this maximal temperature for about 20 minutes. Subsequently, the return to ambient temperature was done under $10 \% \mathrm{H}_{2} / \mathrm{N}_{2}$.

X-ray photoelectron spectroscopy (XPS) experiments were performed using an AXIS Ultra DLD Kratos spectrometer equipped with a monochromated aluminum source ( $\mathrm{Al} K \alpha=1486.7$ $\mathrm{eV}$ ) and charge compensation gun. All binding energies were referenced to the $C$ is core level at $285 \mathrm{eV}$. Simulation of the experimental photopeaks was carried out using a mixed Gaussian/Lorentzian peak fit procedure according to the software supplied by CasaXPS. Semiquantitative analysis accounted for a nonlinear Shirley background subtraction.

The magnetic properties of $\mathrm{Ba}_{8} \mathrm{Ta}_{6} \mathrm{NiO}_{24}$ were analyzed using a MPMS SQUID-VSM (Quantum Design) magnetometer in a temperature and field range of 1.8-400 K and 0-7 T.

\section{Results and discussion}

The structure of $\mathrm{Ba}_{8} \mathrm{Ta}_{6} \mathrm{NiO}_{24}$ hexagonal perovskite corresponds to a $8 \mathrm{H}$ (cchc) $)_{2}$ sequence of close-packed $\mathrm{BaO}_{3}$ layers along the hexagonal c axis. It involves the incorporation of facesharing units (h-layers) inside the usual network of corner-shared octahedrons (c-layers). Dealing with pentavalent ions, the strong coulombic repulsion occurring across face shared units may generate full ordering between vacancies and occupied sites, similar to that observed in the $\mathrm{Ba}_{5} \mathrm{Ta}_{4} \mathrm{O}_{15}$ compound belonging to the studied system (see figure $1 \mathrm{a}$ ). In $\mathrm{Ba}_{8} \mathrm{Ta}_{6} \mathrm{NiO}_{24}$, this phenomenon also occurs but in a more complex manner due to its mixed 
metallic character. The face sharing $\mathrm{M}_{2} \mathrm{O}_{9}$ dimers created at the h-layers are "mainly ordered" in that sense that $1 / 3^{\text {rd }}$ of them consist of $\left(\mathrm{Ta}_{1}\right)\left(\mathrm{V}_{c}\right) \mathrm{O}_{9}$ units (where $\mathrm{V}_{c}$ is a cationic vacancy) while $2 / 3^{\text {rd }}$ of them correspond to $\left(\mathrm{Ta}_{0.85} \mathrm{~V}_{\mathrm{c} 0.15}\right)\left(\mathrm{Ta}_{0.15} \mathrm{Ni}_{0.75} \mathrm{~V}_{\mathrm{c} 0.1}\right) \mathrm{O}_{9}$ dimers. These dimers are ordered in the $(a, b)$ plane (see figure $1 b)$ in a cooperative manner responsible for the large in-plane lattice constant $(a=10.07458(6) \AA$ and $c=19.0122(2) \AA$.$) and the non-$ centrosymmetric space group $\mathrm{P}_{3} \mathrm{~cm}$. In addition, as mentioned above, the Ni replacement by a bench of other metals (Co, Zn...) make the dimers rather versatile units susceptible of numerous modifications that may affect the macroscopic properties.

In a first step, we have checked the validity of the reported structural data by means of Rietveld refinement of the XRD data. Starting from the reported model, various site occupancies have been tested but confirm the proposed distribution as the best model, see figure 1b. Our final refinement leads to $a=10.0706(2) \AA$ and $c=19.0096(9) \AA$ with $R_{\text {Bragg }}=5.62$ \%. Especially all attempts to re-organize the two independent dimeric units in the centrosymmetric $\mathrm{P}_{3} / \mathrm{mmc}$ space group in which both octahedra of a dimer are equivalent by mirror symmetry clearly failed in terms of agreement factors. In the next stage, a treatment in ammonia as described in the experimental section was applied to this precursor at various incremental temperatures. From $450{ }^{\circ} \mathrm{C}$ to $700{ }^{\circ} \mathrm{C}$, no modification of the precursor aspect was observed. The treated phases kept the same pale green color than the pristine compound without any modification of the XRD patterns. In addition, no significant amount of nitrogen in the resulting solids was detected after verification from our analysis (see experimental section for method).

At $1000^{\circ} \mathrm{C}$, the powder turned from pale green to black, although the amount of nitrogen measured remains negligible, while the XRD pattern revealed only a small variation of the cell parameters.

XRD patterns of $\mathrm{Ba}_{8} \mathrm{Ta}_{6} \mathrm{NiO}_{24}$ precursor and of the modified sample treated at $1000{ }^{\circ} \mathrm{C}$ are shown in figure 2 with evidence of an almost unchanged XRD patterns. We note the presence of $\mathrm{Ba}_{5} \mathrm{Ta}_{4} \mathrm{O}_{15}$ second phase in a minor but detected amount despite the numerous heat treatments with intermediate grindings. Besides, the absence of nitrogen and a decrease of the oxygen content compared to the pristine phase are highlighted by our analysis (see experimental section for method). The later have been precisely quantified by 
TGA as shown later. The impurity however seems unaffected by the $\mathrm{NH}_{3}$-treatment. Structural investigation will be further discussed in the refinement section (figure 3).

Nevertheless, evidence of modifications is revealed from TEM images of a crystallite that show the presence of nanoparticles at the surface of the crystallites, as shown on figure 4. The EDS mapping (fig 4c) of those nanoparticles revealed that their chemical nature consists in Nickel element. It thus confirms the presence of Ni nanoparticles at the surface of the crystallites. The estimated diameter is 50 to $100 \mathrm{~nm}$. An in situ high temperature TEM study up to $800{ }^{\circ} \mathrm{C}$ (fig 4d) showed the stability of these particles with no evidence of further crystal growth on heating. The shape deformation of the particle is only due to a little tilt induced by the heating process. It suggests that the $\mathrm{Ni}$ depletion has reached its maximal value during the initial ammonolysis treatment.

At this stage, in absence of quantitative Ni titration, the ammonolysis leads to the generic formula $\mathrm{Ba}_{8} \mathrm{Ta}_{6} \mathrm{Ni}_{1-\mathrm{x}} \mathrm{O}_{24-\mathrm{y}}$. XPS measurements confirm the contribution of both $\mathrm{Ni}^{0}$ and $\mathrm{Ni}^{2+}$ in good agreement with a partial exsolution of $\mathrm{Ni}^{2+}$ into $\mathrm{Ni}^{0}$, see $\mathrm{S} 1$. It is accompanied by an oxygen loss which allows balancing the charges, keeping the $\mathrm{Ni}^{2+}$ and $\mathrm{Ta}^{5+}$ initial oxidation states. After the $\mathrm{NH}_{3}$-treatment at $1000{ }^{\circ} \mathrm{C}$, the slight shift of the main phase peaks lead to the lattice parameters $a=10.0870(8) \AA$ and $c=18.9873(1) \AA$.

The XRD analysis of the residue resulting from the TGA in air (performed from room temperature to $1300{ }^{\circ} \mathrm{C}$ ) show that the previous minor impurity $\mathrm{Ba}_{5} \mathrm{Ta}_{4} \mathrm{O}_{15}$ turned into $\mathrm{Ba}_{3} \mathrm{NiTa}_{2} \mathrm{O}_{9}$, plausibly after a reaction with the exsolved nickel. Then, after several reheating at $1350^{\circ} \mathrm{C}$, the initial situation (before $\mathrm{NH}_{3}$ treatment) could fully be recovered, i.e. almost pure $\mathrm{Ba}_{8} \mathrm{Ta}_{6} \mathrm{NiO}_{24}$ with a minor amount of $\mathrm{Ba}_{5} \mathrm{Ta}_{4} \mathrm{O}_{15}$ and the initial pale green-yellow color of the powder. Thus, the Ni exsolution process is reversible as will be further supported below.

The refined lattice parameters for the main phase $\mathrm{Ba}_{8} \mathrm{Ta}_{6} \mathrm{Ni}_{1-\mathrm{x}} \mathrm{O}_{24-y}$ are presented in the table 1.

Under $10 \%-\mathrm{H}_{2}$ flow up to about $1000{ }^{\circ} \mathrm{C}$, the pristine compound is inert and no weight mass loss or gains appear during the TGA analysis, with no color variation observed, the powder remaining pale green. It shows the remarkable stability of the pristine compound towards reducing atmospheres even at high temperatures, and highlights the specific reactivity of 
$\mathrm{NH}_{3}$, a well-known reducing agent in selective catalysis involving the dissociation reaction $2 \mathrm{NH}_{3} \rightarrow \mathrm{N}_{2}+3 \mathrm{H}_{2}$, see figure 5 .

In air, the $\mathrm{NH}_{3}$-treated $\mathrm{Ba}_{8} \mathrm{Ta}_{6} \mathrm{Ni}_{1-\mathrm{x}} \mathrm{O}_{24-\mathrm{y}}$ sample shows a weight gain with multiple steps at around $400{ }^{\circ} \mathrm{C}, 750{ }^{\circ} \mathrm{C}$ and $1250{ }^{\circ} \mathrm{C}$. These weight gains correspond respectively, to $0.11 \%$, $0.15 \%$ and $0.05 \%$ of the total mass of the sample. A weight loss also appears at around 550 ${ }^{\circ} \mathrm{C}$ and represents $0.03 \%$ of the total mass of the sample (see figure 5 ).

The peculiar multi-step TGA-air mass variation is due to the complexity of the reactional mechanism involved in the reoxidation of the phase. With respect to the XRD analysis of the TGA residue, we assume that the mass increases are due to oxygen absorption closely linked to the reinsertion of $\mathrm{Ni}^{2+}$ ions from the nanosized Nickel particles into the system. Indeed, $\mathrm{Ba}_{5} \mathrm{Ta}_{4} \mathrm{O}_{15}$ is reacting first to form the intermediate $\mathrm{Ba}_{3} \mathrm{NiTa}_{2} \mathrm{O}_{9}$ and reappears after further heat treatments, and then as mentioned above the initial situation is recovered. Also, the particular behavior of $\mathrm{Ni}$ nanoparticles compared to bulk nickel could explain a multi-step TGA. As reported in the literature [30], TGA of nanosized Ni leads to an initial oxidation and a melting temperature of nickel nanoparticles occurring around 300 and $500{ }^{\circ} \mathrm{C}$, respectively, i.e. much smaller than the bulk values.

A stoichiometry can be calculated out of these mass variations, which lead to a formulation for the compound after $\mathrm{NH}_{3}$ treatment where around half of the Nickel is exsoluted out of the structure: $\mathrm{Ba}_{8} \mathrm{Ta}_{6} \mathrm{Ni}_{0.487} \mathrm{O}_{23.575}$. The $\mathrm{Ni}$ titration will be confirmed later by means of magnetization measurements.

We have characterized the Ni-depleted phase using a high quality XRD pattern. The Rietveld refinement was performed using the pristine compound structural model in the noncentrosymmetric (NCS) $P 6_{3} \mathrm{~cm}$ and modified in the centrosymmetric (CS) $\mathrm{PG}_{3} / \mathrm{mcm}$ space groups (figure 3 and table 1). Here the convergence was reached using a compositional restraint according to the above formula. The best fit $\left(R_{B r a g g}=8.68 \%\right)$ was obtained keeping the NCS symmetry with ordering between two kinds of dimers: $\left(\mathrm{Ta}_{1}\right)\left(\mathrm{V}_{c}\right) \mathrm{O}_{9}\left(1 / 3^{\text {rd }}\right)$ and $\left(\mathrm{Ta}_{0.68} \mathrm{~V}_{\mathrm{c} 0.32}\right)\left(\mathrm{Ta}_{0.32} \mathrm{Ni}_{0.37} \mathrm{~V}_{\mathrm{c} 0.31}\right) \mathrm{O}_{9-\mathrm{x}}\left(2 / 3^{\text {rd }}\right)$ which involves the preservation of $\mathrm{Ni}^{2+}$ at one unique side of the mixed $\mathrm{Ta} / \mathrm{Ni}$ dimers, comfortingly to the main formula $\mathrm{Ba}_{8} \mathrm{Ta}_{6} \mathrm{Ni}_{0.5} \mathrm{O}_{23.5}$. It is sketched figure 1c. Table 1 gathers the final reliability factors R values for both NCS and CS 
space groups for the exsoluted material and the pristine compound. The pristine compound recovered after air-annealing of the exsoluted compound (table 1) give similar refinement results than the initial sample from synthesis, confirming the full reversibility.

The exsolution of $50 \%$ of the initial nickel amount can be easily understand taking into account the versatile $\mathrm{Ni}^{2+}$ coordination (IV, V, VI) compared to $\mathrm{Ta}^{5+}$ (VI or more). Then, the removal of one $\mathrm{Ni}^{2+}$ being systematically accompanied by the creation of one oxygen vacancy, the later should be located solely around the remaining $\mathrm{Ni}^{2+}$ cations, following the reduction reaction : $2 \mathrm{Ni}^{2+}+\mathrm{O}^{2-}+\mathrm{H}_{2} \rightarrow \mathrm{Ni}^{2+}+\mathrm{Ni}^{0}+\mathrm{H}_{2} \mathrm{O}$ which rules out the removal of half of the $\mathrm{Ni}^{2+}$ amount and oxygen amount in equimolar ratio. If one excludes the creation of $\mathrm{Vc}_{2} \mathrm{O}_{9}$ empty dimers, the ideal $\mathrm{M}(1,2)_{2} \mathrm{O}_{9-x}$ distribution would be $\mathrm{Ta}_{2} \mathrm{O}_{9}(37.5 \%), \mathrm{TaVcO}_{9}(25 \%)$ and $\left(\mathrm{NiVcO}_{8}\right)(37.5 \%)$, see figure 1e. Finally, it follows that the exsolution of $\mathrm{Ni}$ metal nanoparticles out of the solid is associated to the rearrangement of the cations in the pair of octahedrons while Nickel leaves his site (mixed site $\mathrm{Ta} / \mathrm{Ni} / \mathrm{Vc}$ ) and reduces as metal Ni-nano at the surface, the subsequent increase of vacancies in this site may be compensated by partial migration of tantalum from the $\mathrm{Ta} / \mathrm{Vc}$ site of the dimer to balance occupations between both octahedrons of the dimer. The migration of $\mathrm{Ni}^{2+}$ cations should be facilitated in-plane trough the vacant sites.

Table 1: Cell parameters obtained via Rietveld refinements and reliability factors, in two different space groups: $P G_{3} \mathrm{Cm}$ (NCS) and $P G_{3} / \mathrm{mcm}$

\begin{tabular}{|c|c|c|c|c|}
\hline & \multicolumn{2}{|c|}{ Pristine compound $\mathrm{Ba}_{8} \mathrm{Ta}_{6} \mathrm{NiO}_{24}$} & \multicolumn{2}{|c|}{ After $\mathrm{NH}_{3} 1000^{\circ} \mathrm{C}$} \\
\hline Space group & $\mathrm{PG}_{3} \mathrm{Cm}$ (NCS) & $\mathrm{P}_{3} / \mathrm{mcm}(\mathrm{CS})$ & $\mathrm{P6}_{3} \mathrm{Cm}(\mathrm{NCS})$ & $\mathrm{P}_{3} / \mathrm{mcm}(\mathrm{CS})$ \\
\hline $\mathrm{a}(\AA)$ & \multicolumn{2}{|c|}{$10.0706(2)$} & \multicolumn{2}{|c|}{$10.0870(8)$} \\
\hline c $(\AA)$ & \multicolumn{2}{|c|}{ 19.0096(9) } & \multicolumn{2}{|c|}{ 18.9873(1) } \\
\hline$V\left(\AA^{3}\right)$ & \multicolumn{2}{|c|}{1669.61} & \multicolumn{2}{|c|}{1673.10} \\
\hline$\chi^{2}$ & 5.72 & 7.59 & 10.3 & 14.4 \\
\hline $\begin{array}{c}\text { Bragg R-factor } \\
\text { (\%) }\end{array}$ & 5.62 & 5.19 & 8.68 & 15.21 \\
\hline
\end{tabular}




\begin{tabular}{|l|l|l|l|l|}
\hline R-Factor (\%) & 4.50 & 10.9 & 4.82 & 13.0 \\
\hline
\end{tabular}

\section{Magnetic measurements}

The magnetism of the title precursor phase was investigated and shows a typical paramagnetic behavior as evidenced by the Brillouin-type magnetization plot at low temperature (see figure 6). At $\mathrm{T}=2 \mathrm{~K}, \mu_{0} \mathrm{H}=7 \mathrm{~T}$ the magnetization is not saturated but reaches $M_{\text {para init }}=1.99 \mu_{\mathrm{B}} / \mathrm{Ni}$ which shows an easy alignment of paramagnetic ions. The Curie-Weiss fit of $\chi(T)$ in the temperature range $5-400 \mathrm{~K}$ leads to $\theta=-0.92(3) \mathrm{K}$ and an effective moment $\mu_{\text {eff }}=3.1 \mu_{\mathrm{B}} / \mathrm{Ni}$. This value agrees well with the spin-only value expected for $\mathrm{Ni}^{2+}\left(2.83 \mu_{\mathrm{B}} / \mathrm{Ni}\right)$ and with experimental values reported in the literature, usually ranging from $\sim 2.9$ to $\sim 3.9 \mu_{\mathrm{B}}$ [31]. After ammonia treatment, the magnetization is dominated by the ferromagnetic contribution of Ni metal consistently with the magnetization step superposed to the initial paramagnetic behavior. At $\mathrm{T}=2 \mathrm{~K}, \mu_{0} \mathrm{H}=7 \mathrm{~T}$ the magnetization can be decomposed into two contribution $\mathrm{M}_{\text {para NH3 }}=0.95 \mu_{\mathrm{B}} / \mathrm{FU}$ and $\mathrm{M}_{\mathrm{Ni}}=0.28 \mu_{\mathrm{B}} / \mathrm{FU}$. Both values comfort the exsolution of $50 \%$ of the initial nickel content into metallic islets since: i) the

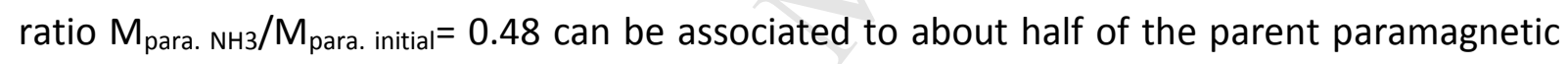
contribution, and ii) the $\mathrm{M}_{\mathrm{Ni}}$ value corresponds to about $0.47 \mathrm{Ni} / \mathrm{FU}$. On the basis of previous work on the magnetic behavior of nanocrystalline nickel after annealing at $1000^{\circ} \mathrm{C}$, the saturation magnetization was reported to be ca. $0.6 \mu_{\mathrm{B}} / \mathrm{Ni}$ [32], the moment value known also for bulk metallic Ni. This amount of exsoluted metallic nickel involves a bulk material with the formulae $\mathrm{Ba}_{8} \mathrm{Ta}_{6} \mathrm{Ni}_{0.53} \mathrm{O}_{23.5}$, very close to the one calculated from the TGA analysis.

\section{Catalytic activity for the DRM}

The results of catalytic tests for dry reforming of methane $\left(\mathrm{CH}_{4}+\mathbf{C O}_{\mathbf{2}}=>\mathbf{2 C O}+\mathbf{2} \mathrm{H}_{2}\right)$ are reported in figure 7. The catalyst $\mathrm{NH}_{3}$-treated sample shows an activity of both reactants, with conversion starting at $40 \%$ then stabilizing at $30 \%$ for $\mathrm{CH}_{4}$ and starting at $30 \%$ then stabilizing at $20 \%$ for $\mathrm{CO}_{2}$. Such values are lower than the maximum conversion allowed by thermodynamics in such conditions, but our catalyst is clearly active for syngas production. After an initial loss of conversion at the beginning of the experiment, the activity becomes stable. This could be due to some sintering of the nickel particles or to the coking of the surface as suggested by the higher methane conversion with respect to that of carbon 
dioxide. The selectivity toward hydrogen is reported in the same graph. It starts around $50 \%$ and stabilizes to $30 \%$ which is rather moderate. The lower hydrogen selectivity, and corresponding water production could be induced by partial reduction of our sample or, more probably, by reverse water gas shift reaction $\mathrm{CO}_{2}+\mathrm{H}_{2} \rightleftharpoons \mathrm{CO}+\mathrm{H}_{2} 0$. The activity in our system seems therefore limited in these conditions. It should however be noticed that surface area of this sample is very low (less than $1 \mathrm{~m}^{2} \mathrm{gr}^{-1}$ ) if compared to usual catalysts studies for DRM. The low Ni content in the phase $\mathrm{Ba}_{8} \mathrm{Ta}_{6} \mathrm{NiO}_{24}$ can be also pointed, à fortiori since only half of the $\mathrm{Ni}$ was exsoluted as active $\mathrm{Ni}$ nanoparticles at the surface. The performances of our catalyst compares well with similar low $\mathrm{Ni}$-content exsoluted systems such as the standard perovskite compound $\mathrm{La}_{0.46} \mathrm{Sr}_{0.34} \mathrm{Ti}_{0.9} \mathrm{Ni}_{0.1} \mathrm{O}_{3}$ [33]. These results are therefore encouraging as they open interesting perspectives for system optimization. Finally, SEM images are shown in figure 8 before and after the catalytic test for the exsoluted sample. They show particles with sizes of few tens of microns and with an irregular surface state. The general microstructure seems rather similar after the catalytic test.

\section{Conclusion}

The hexagonal perovskite oxide $\mathrm{Ba}_{8} \mathrm{Ta}_{6} \mathrm{NiO}_{24}$ was treated in ammonia with subsequent partial $\mathrm{Ni}$ exsolution at the surface of the parent oxide as confirmed by TEM. The parent oxide is preserved except the partial $\mathrm{Ni}$ exsolution from an octahedral site related to the unique hexagonal layer of the unit cell accompanied by oxygen loss balancing the cations loss, leaving oxygen vacancies and partially depleted and rearranged $\mathrm{Ni} / \mathrm{Ta}$ sites. Indeed, no major modification was observed by XRD-measurements while a drastic color change occurs from pale green to black due to the formation of Ni nanoparticles. It is rather remarkable that, although low amounts, the $\mathrm{Ni}^{2+}$ residual stoichiometry together with the oxygen loss could be precisely evaluated from TGA and magnetic measurements. The catalytic behavior of the Ni-decorated sample was also investigated toward syngas production by DRM. Although activity and selectivity remain low, they offer interesting perspectives for this reaction. While $\mathrm{Ni}$ exsolution is known to occur in some cubic-type perovskites with subsequent catalytic properties, it is uncommon for hexagonal Perovskites. Therefore, searching in similar systems with various proportion of hexagonal layers and with $\mathrm{Ni}$ within 
the structure should open new perspectives and candidates for similar intelligent catalysts with reversible $\mathrm{Ni}$ exsolution.

\section{Acknowledgments}

This work was carried out under the framework of the ANION-CO project supported by the ANR (Grant ANR-12-JS08-0012). The “Fonds Européen de Développement Régional” (FEDER), CNRS, Région Nord Pas-de-Calais, and Ministère de l'Enseignement Supérieur et de la Recherche are acknowledged for funding of the X-ray diffractometers. Martine Trentesaux is thanked for XPS measurements. Olivier Gardoll is thanked for TGA-H measurements. The TEM facility in Lille (France) is supported by the "Conseil Regional des Hauts-de-France" and the "European Regional Development Fund (ERDF). Rose-Noëlle Vannier is thanked for fruitful discussions.

\section{REFERENCES}

[1] M. Morcrette, P. Rozier, L. Dupont, E. Mugnier, L. Sannier, J. Galy, J.M. Tarascon, A reversible copper extrusion-insertion electrode for rechargeable Li batteries, Nature Materials 2 (2003) 755761.

[2] C. H. Bartholomew, Carbon deposition in steam reforming and methanation, Catalysis ReviewsScience and Engineering 24 (1982) 67-112.

[3] K. Takehira, Highly dispersed and stable supported metal catalysts prepared by solid phase crystallization method, Catalysis Surveys from Japan 6 (2002) 19-32.

[4] Y. X. Li, Y. Wang, W. Doherty, K. Xie, Y. C. Wu, Perovskite Chromates Cathode with Exsolved Iron Nanoparticles for Direct High-Temperature Steam Electrolysis, Acs Applied Materials \& Interfaces 5 (2013) 8553-8562

[5] H. Kabbour, R. David, A. Pautrat, H.-J. Koo, M.-H. Whangbo, G. André, O. Mentré, A Genuine TwoDimensional Ising Ferromagnet with Magnetically Driven Re-entrant Transition, Angewandte Chemie International Edition 51 (2012) 11745-11749.

[6] I. Blazquez Alcover, S. Daviero-Minaud, R. David, D. Filimonov, M. Huvé, J.P. Attfield, H. Kabbour, O. Mentré, Selective Metal Exsolution in $\mathrm{BaFe}_{2-y} \mathrm{M}_{\mathrm{y}}\left(\mathrm{PO}_{4}\right)_{2}\left(\mathrm{M}=\mathrm{Co}^{2+}, \mathrm{Ni}^{2+}\right)$ Solid Solutions, Inorganic Chemistry 54 (2015) 8733-8743

[7] I. Blazquez Alcover, R. David, S. Daviero-Minaud, D. Filimonov, M. Huvé, P. Roussel, H. Kabbour, O. Mentré, Reversible Exsolution of Nanometric $\mathrm{Fe}_{2} \mathrm{O}_{3}$ Particles in $\mathrm{BaFe}_{2-x}\left(\mathrm{PO}_{4}\right)_{2}(0 \leq x \leq 2 / 3)$ : The Logic 
of Vacancy Ordering in Novel Metal-Depleted Two-Dimensional Lattices, Crystal Growth and Design 15, (2015) 4237-4247

[8] Y.-F. Sun, Y.-L. Yang, J. Chen, M. Li, Y.-Q. Zhang, J.-H. Li, B. Hua, J.-L. Luo, Toward a rational photocatalyst design: A new formation strategy of co-catalyst/semiconductor heterostructures: Via in situ exsolution, Chemical Communications 54 (2018) 1505-1508

[9] B. D. Madsen, W. Kobsiriphat, Y. Wang, L. D. Marks, S. Barnett, SOFC anode performance enhancement through precipitation of nanoscale catalysts., ECS Trans. 7 (2007) 1339-1348

[10] D. Neagu, E.I. Papaioannou, W.K.W. Ramli, D.N. Miller, B.J. Murdoch, H. Ménard, A. Umar, A.J. Barlow, P.J. Cumpson, J.T.S. Irvine, I.S. Metcalfe, Demonstration of chemistry at a point through restructuring and catalytic activation at anchored nanoparticles, Nature Communications 8 (2017) Article number 1855

[11] W. T. Wallace, B. K. Min, D. W. Goodman, The nucleation, growth, and stability of oxidesupported metal clusters, Topics in Catalysis 34 (2005) 17-30.

[12] S. P. Jiang, Nanoscale and nano-structured electrodes of solid oxide fuel cells by infiltration: Advances and challenges, International Journal of Hydrogen Energy 37 (2012) 449-470.

[13] S. Helveg, C. Lopez-Cartes, J. Sehested, P. L. Hansen, B. S. Clausen, J. R. Rostrup-Nielsen, F. AbildPedersen, J. K. Norskov, Atomic-scale imaging of carbon nanofiber growth. Nature 427 (2004) 426429.

[14] Lerner, B.A., Zhang, Z., Sachtler, W.M.H., Deactivation mechanisms of palladium in methylcyclopentane conversion, Journal of the Chemical Society, Faraday Transactions 89, (1993) 1799-1804

[15] Y. F. Sun, J. H. Li, Y. M. Zeng, B. S. Amirkhiz, M. N. Wang, Y. Behnamian, J. L. Luo, A-site deficient perovskite: the parent for in situ exsolution of highly active, regenerable nano-particles as SOFC anodes, Journal of Materials Chemistry A 3 (2015) 11048-11056.

[16] R. Shiozaki, A. G. Andersen, T. Hayakawa, S. Hamakawa, K. Suzuki, M. Shimizu, K. Takehira, Partial oxidation of methane over a $\mathrm{Ni} / \mathrm{BaTiO}_{3}$ catalyst prepared by solid phase crystallization. Journal of the Chemical Society-Faraday Transactions 93 (1997) 3235-3242.

[17] M. B. Katz, S. Y. Zhang, Y. W. Duan, H. J. Wang, M. H. Fang, K. Zhang, B. H. Li, G. W. Graham, X. Q. Pan, Reversible precipitation/dissolution of precious-metal clusters in perovskite-based catalyst materials: Bulk versus surface re-dispersion, Journal of Catalysis 293 (2012) 145-148.

[18] W. Kobsiriphat, B. D. Madsen, Y. Wang, L. D. Marks, S. A. Barnett, $\mathrm{La}_{0.8} \mathrm{Sr}_{0.2} \mathrm{Cr}_{1-\mathrm{x}} \mathrm{Ru}_{\mathrm{x}} \mathrm{O}_{3 \text {-delta- }}$ $\mathrm{Gd}_{0.1} \mathrm{Ce}_{0.9} \mathrm{O}_{1.95}$ solid oxide fuel cell anodes: Ru precipitation and electrochemical performance. Solid State lonics 180 (2009) 257-264. 
[19] J. Guerrero-Caballero, A. Löfberg, O. Mentré, T. Kane, T. Pussacq, P. Roussel, M. Huvé, M. Trentesaux, O. Gardoll, H. Kabbour. A Performant Dry Reforming Catalytic System Elaborated from the Reductive Decomposition of $\mathrm{BaNi}_{2} \mathrm{~V}_{2} \mathrm{O}_{8}$, Chemistry Select. 1, (2016) 5633-5637

[20] M. L. Gong, F. Q. Lu, X. J. Kuang, X. D. Yu, Q. C. Wang, X. H. Li, L. Fang, Molten Salt Synthesis, Polymorphism, and Microwave Dielectric Properties of Ba8NiTa6O24 Perovskite. Journal of the American Ceramic Society 98 (2015) 2451-2458.

[21] A. Kan, H. Ogawa, A. Yokoi, H. Ohsato, Microwave dielectric properties of perovskite-like structured $\mathrm{Ba}_{8} \mathrm{Ta}_{6}\left(\mathrm{Ni}_{1-\mathrm{x}} \mathrm{M}_{\mathrm{x}}\right)(\mathrm{M}=\mathrm{Co}, \mathrm{Cu}$, and $\mathrm{Zn}$ ) solid solutions, Japanese Journal of Applied Physics Part 1-Regular Papers Brief Communications \& Review Papers 45 (9B) (2006) 7494-7498.

[22] E. M. Kopnin, A. A. Belik, R. V. Shpanchenko, E. V. Antipov, F. Izumi, E. Takayama-Muromachi, J. Hadermann, Synthesis, crystal structure, and magnetic properties of new layered hexagonal perovskite $\mathrm{Ba}_{8} \mathrm{Ta}_{4} \mathrm{Ru}_{8 / 3} \mathrm{Co}_{2 / 3} \mathrm{O}_{24}$, Journal of Solid State Chemistry 177 (2004) 3499-3504

[23] S. Kawaguchi, H. Ogawa, A. Kan, S. Ishihara, Microwave dielectric properties of $\mathrm{Ba}_{8} \mathrm{Ta}_{6}\left(\mathrm{Ni}_{1}\right.$ $\left.{ }_{x} \mathrm{M}_{\mathrm{x}}\right) \mathrm{O}_{24}(\mathrm{M}=\mathrm{Zn}$ and $\mathrm{Mg}$ ) ceramics, Journal of the European Ceramic Society 26 (2006) 2045-2049 [24] J. Cao, X. J. Kuang, M. Allix, C. Dickinson, J. B. Claridge, M. J. Rosseinsky, D. M. Iddles, Q.S u, New 8-Layer Twinned Hexagonal Perovskite Microwave Dielectric Ceramics $\mathrm{Ba}_{8} \mathrm{Ga}_{4-\mathrm{x}} \mathrm{Ta}_{4+0.6 x} \mathrm{O}_{24}$, Chemistry of Materials 23 (2011) 5058-5067

[25] M. Thirumal, P. K. Davies, $\mathrm{Ba}_{8} \mathrm{ZnTa}_{6} \mathrm{O}_{24}$ : A new high $\mathrm{Q}$ dielectric perovskite. Journal of the American Ceramic Society 88 (2005) 2126-2128

[26] X. D. Yu, S. Q. Chai, X. J. Kuang, C. X. Su, F. J. Pan, L. Fang, Q. Su, Conductivity, Dielectric Loss, and Electrical Heterogeneous Microstructure of Eight-Layer Twinned Hexagonal Perovskite Ceramics

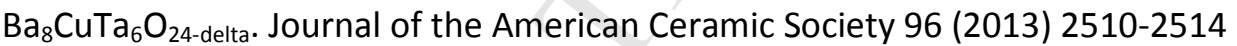

[27] S. M. Moussa, J. B. Claridge, M. J. Rosseinsky, S. Clarke, R. M. Ibberson, T. Price, D. M. Iddles, D. C. Sinclair, $\mathrm{Ba}_{8} \mathrm{ZnTa}_{6} \mathrm{O}_{24}$ : a high-Q microwave dielectric from a potentially diverse homologous series. Applied Physics Letters 82 (2003) 4537-4539

[28] A. M. Abakumov, G. VanTendeloo, A. A. Scheglov, R. V. Shpanchenko, E. V.Antipov, The crystal structure of $\mathrm{Ba}_{8} \mathrm{Ta}_{6} \mathrm{NiO}_{24}$ : Cation ordering in hexagonal perovskites. Journal of Solid State Chemistry 125 (1996) 102-107

[29] J. Rodríguez-Carvajal, Recent Developments of the Program FULLPROF, Commission on powder diffraction (IUCr) Newsletter 26 (2001) 12-19

[30] P. Song, D. Wen, Z. X. Guo and T. Korakianitis, Oxidation investigation of nickel nanoparticles, Phys. Chem. Chem. Phys. 10 (2008) 5057-5065

[31] a) J.R. Thompson, S.T. Sekula, Y. Chen, Magnetic properties of $\mathrm{Ni}$ in $\mathrm{MgO}$; $\mathrm{Ni}^{+2}$ ions and magnetically ordered precipitates, Physica B 107 (1981) 87-88. b) M. Tadic, D. Nikolic, M. Panjan, G. 
R. Blake, Magnetic properties of NiO (nickel oxide) nanoparticles: Blocking temperature and Neel temperature, Journal of Alloys and Compounds 647 (2015) 1061-1068

[32] H. Kisker, H. Kronmuller, H. E. Schaefer, T. Suzuki, Magnetism and microstructure of nanocrystalline nickel, Journal of Applied Physics 79 (1996) 5143-5145.

[33] Y. Chai, Y. Fu, H. Feng, W. Kong, C. Yuan, B. Pan, J. Zhang, Y. Sun, A Nickel-Based Perovskite Catalyst with a Bimodal Size Distribution of Nickel Particles for Dry Reforming of Methane,

\section{FIGURES}

a)

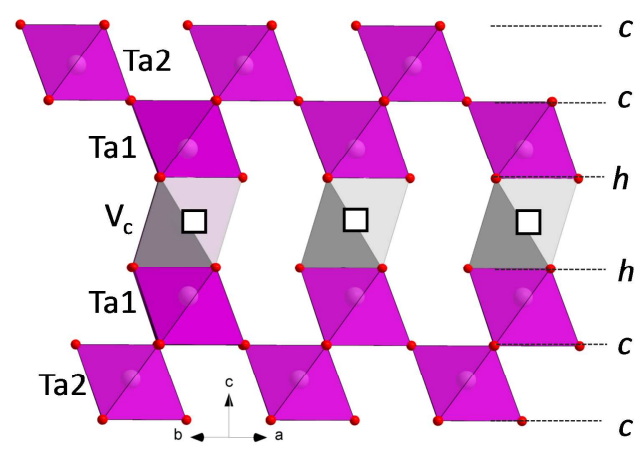

d)

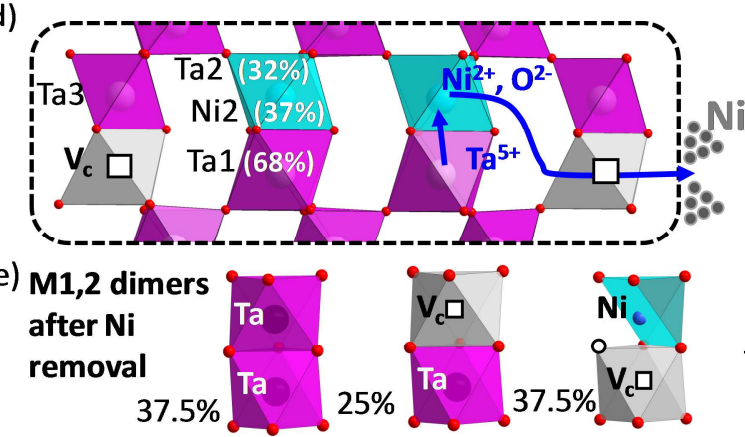

b)
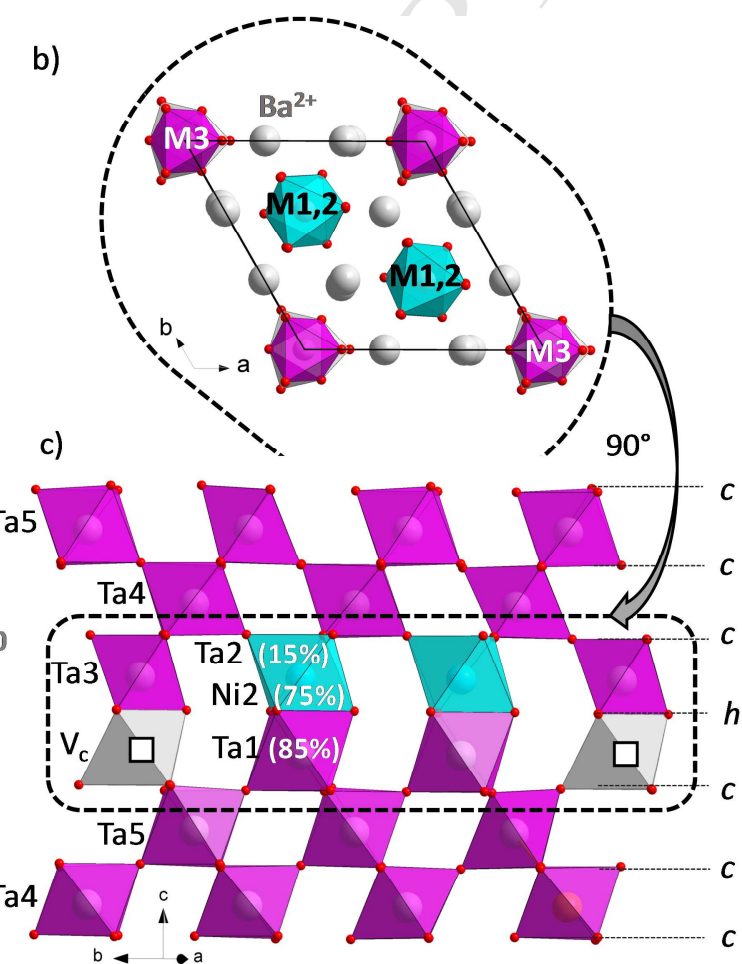

Figure 1: evidence of the cationic ordering in a) $5 \mathrm{H}-\mathrm{Ba}_{5} \mathrm{Ta}_{4} \mathrm{O}_{14}$ (view along the $<-1-10>$ direction). $b$ c) $\mathrm{Ba}_{8} \mathrm{Ta}_{6} \mathrm{NiO}_{24}$ (two views of the selected dimeric slice with $\mathrm{M1}, \mathrm{M} 2$ and $\mathrm{M} 3$ sites. d) cationic reorganization of the hexagonal block after $50 \%$ nickel exsolution into surficial islets. e) Ideal

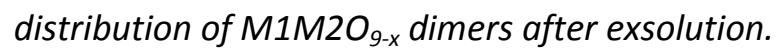




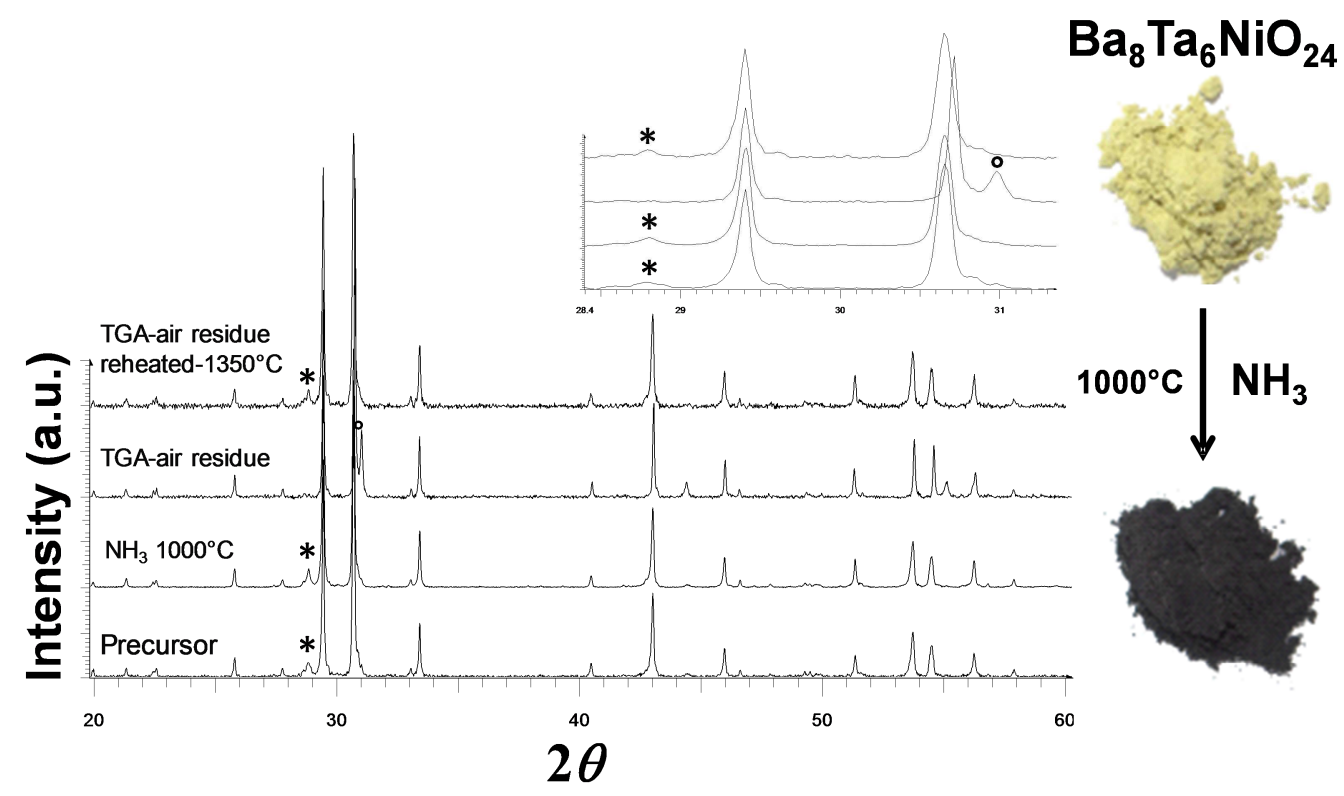

Figure 2: Characterization using X-ray powder diffraction (XRD): $\mathrm{Ba}_{8} \mathrm{Ta}_{6} \mathrm{NiO}_{24}$ phase after

different treatments and analysis: from bottom to top: the precursor $\mathrm{Ba}_{8} \mathrm{Ta}_{6} \mathrm{NiO}_{24}$, the precursor after $\mathrm{NH}_{3}$ treatment at $1000^{\circ} \mathrm{C}$, the later sample after TGA in air (residue), and the later residue after regrinding and reheating at $1350{ }^{\circ} \mathrm{C}$ showing the reversibility of the exsolution (i.e. an identical XRD as the precursor is found as well as the initial color (yellow) is recovered. The inset represents the enlarged plot between $28.5^{\circ}$ and $31.3^{\circ}$, to focus on the presence of two minor impurities: $\mathrm{Ba}_{5} \mathrm{Ta}_{4} \mathrm{O}_{15}$ (stars) and $\mathrm{Ba}_{3} \mathrm{NiTa}_{2} \mathrm{O}_{9}$ (open circles). On the right, pictures of the powder samples are shown: the precursor $\mathrm{Ba}_{8} \mathrm{Ta}_{6} \mathrm{NiO}_{24}$ is yellow and become black after the ammonia treatment at $1000{ }^{\circ} \mathrm{C}$ due to the exsolution of nanosized metallic nickel. 

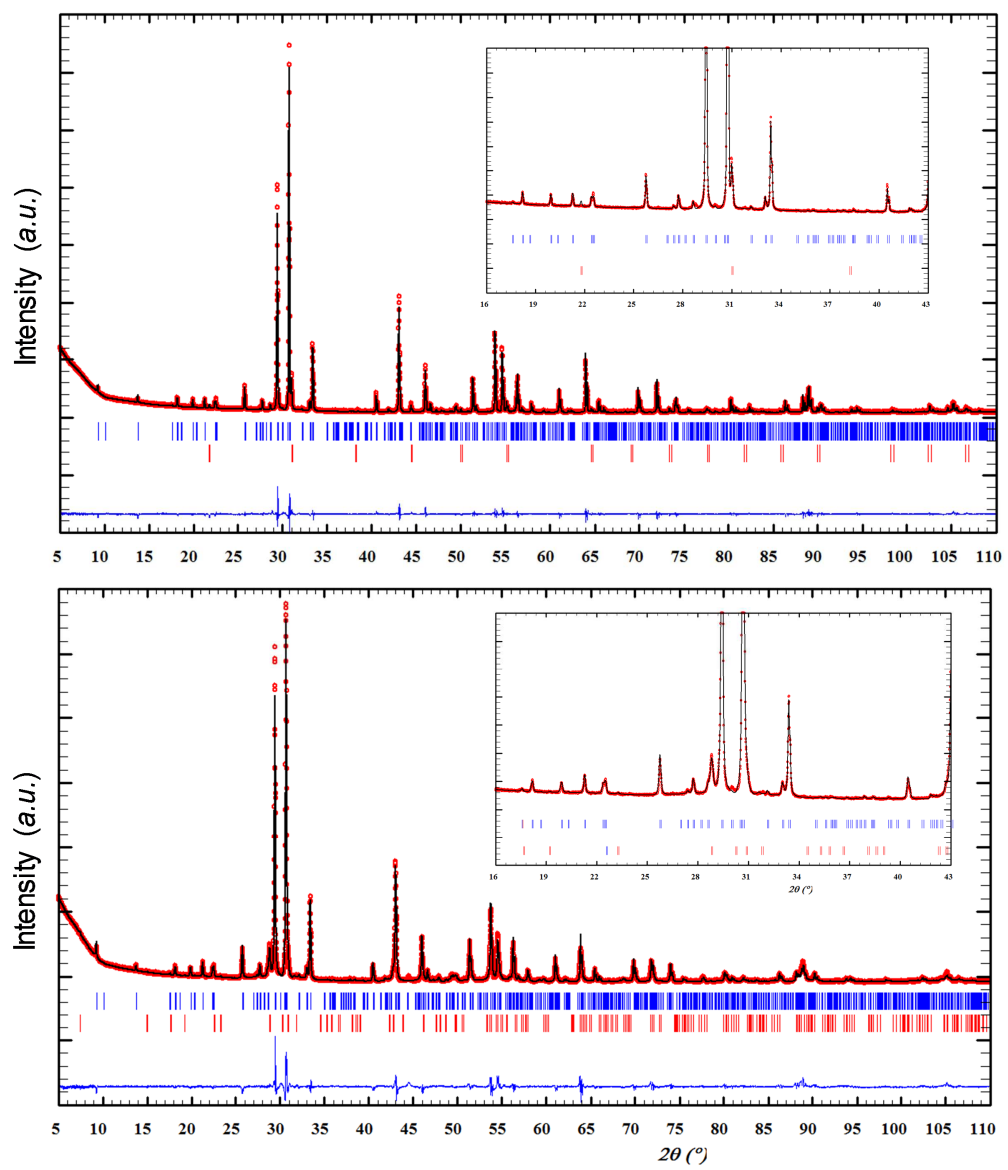

Figure 3: Refinement from powder X-ray Diffraction Data of $\mathrm{Ba}_{8} \mathrm{Ta}_{6} \mathrm{NiO}_{24}$ (top) and $\mathrm{Ba}_{8} \mathrm{Ta}_{6} \mathrm{NiO}_{24}$ after $\mathrm{NH}_{3}$ treatment at $1000{ }^{\circ} \mathrm{C}$ (bottom), in the space group $\mathrm{P} 6_{3} \mathrm{~cm}$. The main phase is represented by blue sticks, the second minority phase by red sticks (i.e. $B a_{5} T a_{4} O_{9}$ or $\mathrm{Ba}_{3} \mathrm{NiTa}_{2} \mathrm{O}_{9}$, respectively) 


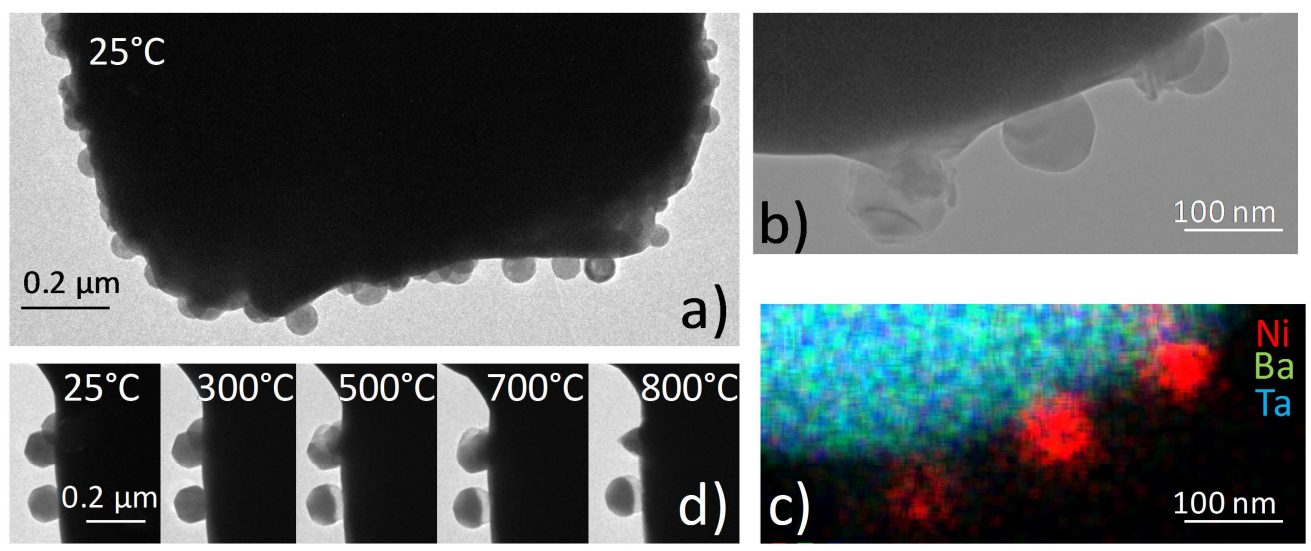

Figure 4: a) TEM images of $\mathrm{NH}_{3}$-treated $\mathrm{Ba}_{8} \mathrm{Ta}_{6} \mathrm{NiO}_{24}$ at room temperature b) enlargement of the border and c) corresponding EDS mapping d) in situ images upon heating from room temperature to $800{ }^{\circ} \mathrm{C}$

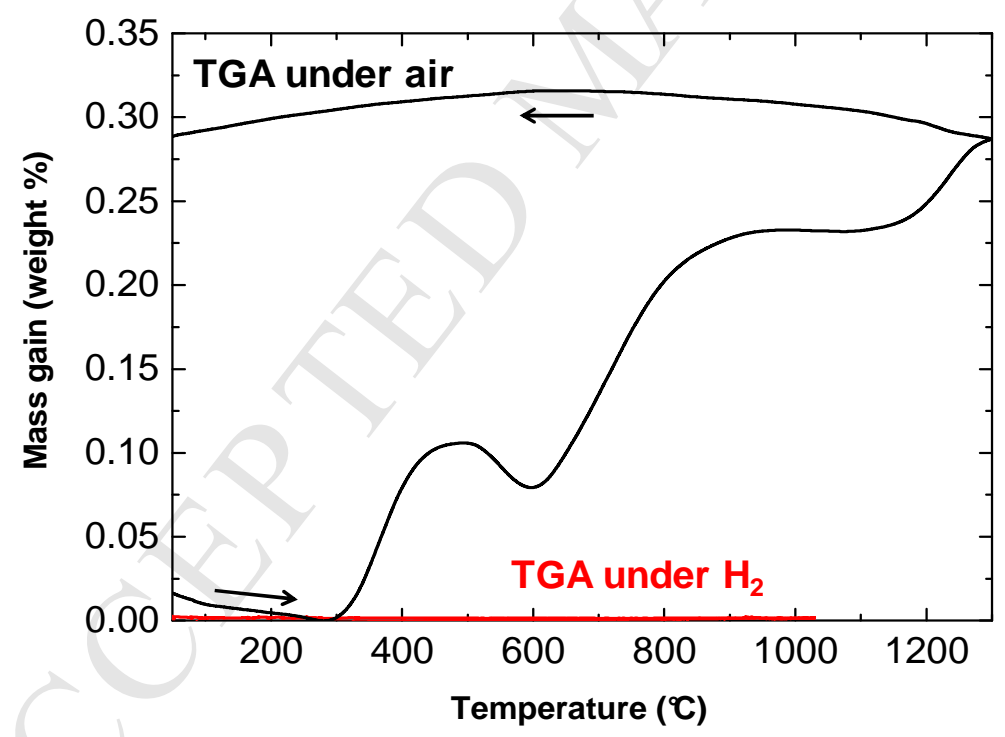

Figure 5: TGA measurements under air from room temperature to $1300^{\circ} \mathrm{C}$ of the $\mathrm{NH}_{3}$-treated compound (black) and TGA measurements under $50 \%-\mathrm{H}_{2}$ flow from room temperature to about $1000^{\circ} \mathrm{C}$ of the pristine compound (red). The arrows indicate the experiment sequence (raising temperature up to $1300^{\circ} \mathrm{C}$, and then cooling back to room temperature) 

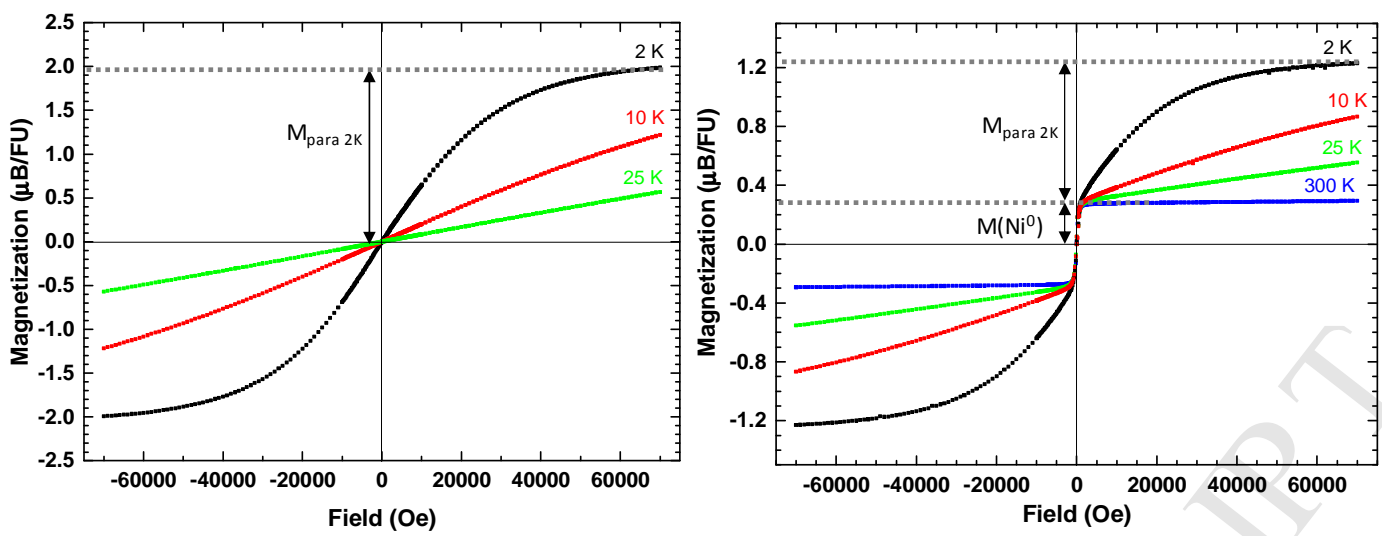

Figure 6: Magnetization of the $\mathrm{Ba}_{8} \mathrm{Ta}_{6} \mathrm{NiO}_{24}$ pristine compound (left) and after $\mathrm{NH}_{3}$-treatment at $1000^{\circ} \mathrm{C}$ (right), at different temperatures. The paramagnetic contribution after saturation at $2 \mathrm{~K}$ is pointed in both cases. In the case of the $\mathrm{NH}_{3}$-treated sample, the metallic nickel contribution is also pointed. 


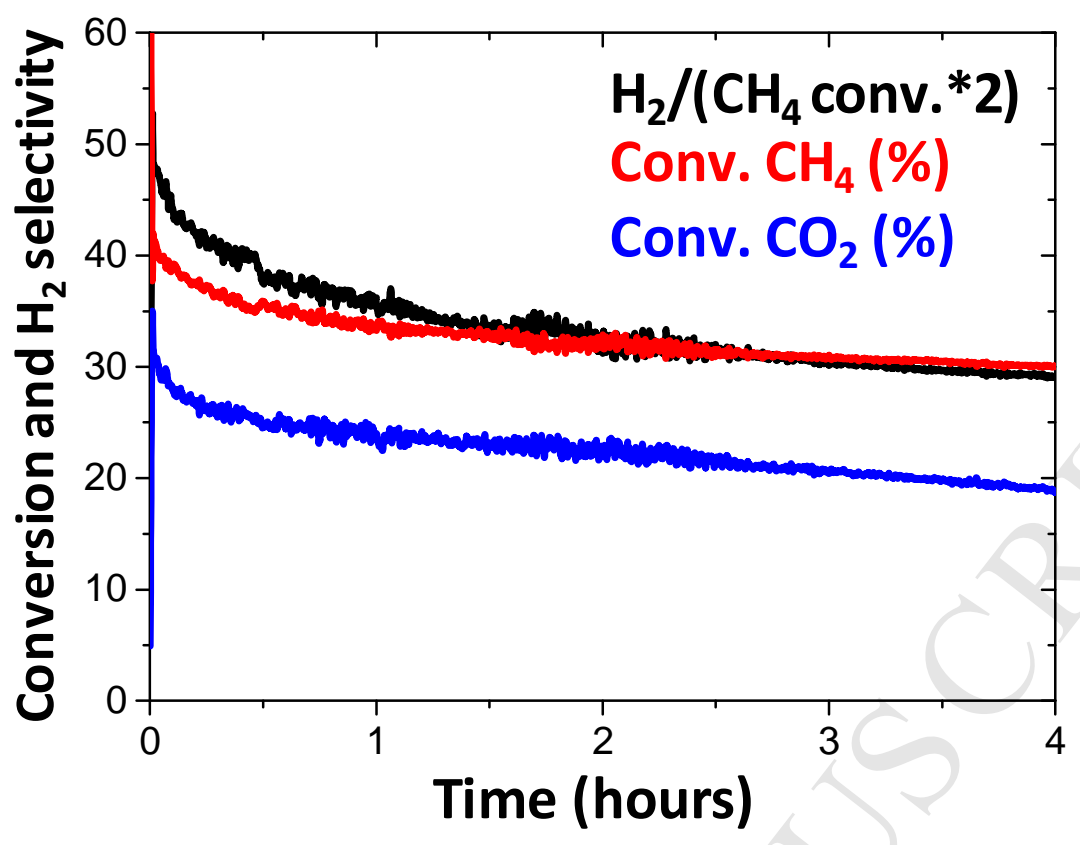

Figure 7: Catalytic activity of $\mathrm{Ba}_{8} \mathrm{Ta}_{6} \mathrm{NiO}_{24}$ after the $\mathrm{NH}_{3}$-treatment at $1000{ }^{\circ} \mathrm{C}$
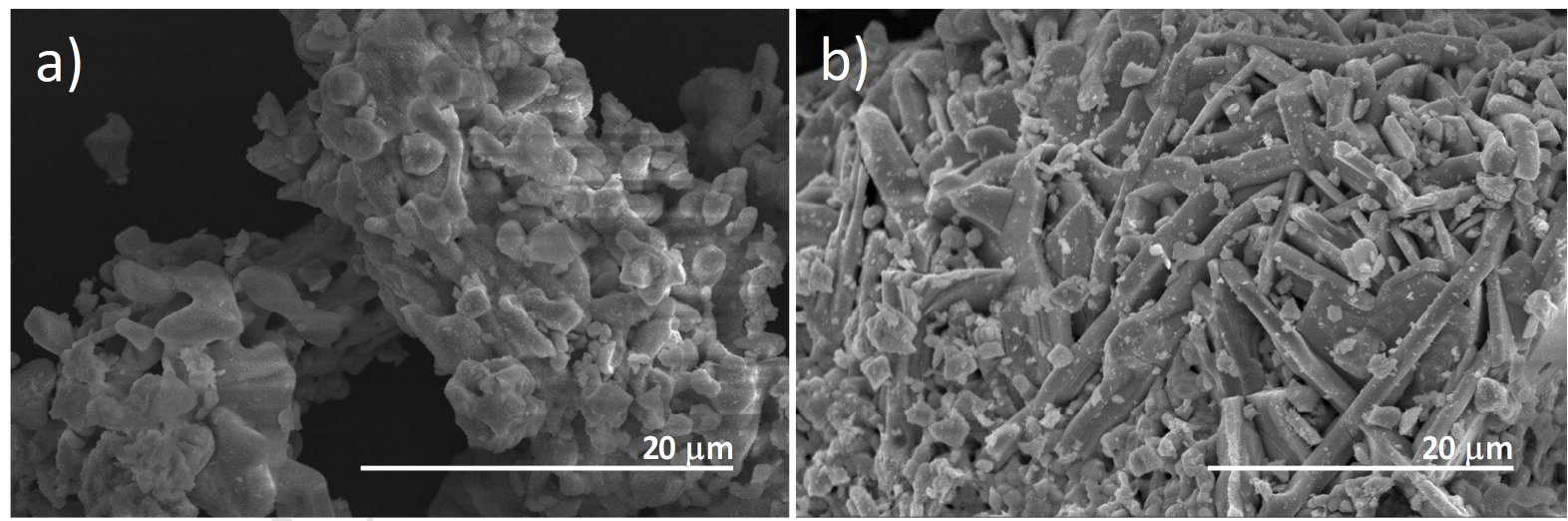

Figure 8: SEM images of $\mathrm{Ba}_{8} \mathrm{Ta}_{6} \mathrm{NiO}_{24}$ after $\mathrm{NH}_{3}-1000^{\circ} \mathrm{C}$ treatment before (a) and after (b) the catalytic test. 


\section{Highlights}

- The hexagonal perovskite $\mathrm{Ba}_{8} \mathrm{Ta}_{6} \mathrm{NiO}_{24}$ shows reversible $\mathrm{Ni}$-exsolution

- The Ni-exsolution generates catalytic activity for dry reforming of methane

- TEM shows that Nickel nanoparticles are exsoluted at the surface

- It involves oxygen vacancies and partially depleted but rearranged $\mathrm{Ni} / \mathrm{Ta}$ sites

- Magnetic properties, refinements and TGA allow quantifying the exsoluted $\mathrm{Ni}$ 